\title{
Towards Establishing A Consumers Claims Tribunal in Jordan - A Way Forward?
}

\author{
Ahmad Ibrahim Al Sharu ${ }^{1 *}$ Dr. Fauziah Binti Mohd Noor ${ }^{2}$ Prof. Rohana Binti Abdul Rahman \\ School of law, Universiti Utara Malaysia, Malaysia \\ * E-mail of the corresponding author: ahmadshr85@yahoo.com
}

\begin{abstract}
Consumers typically look for quick and easy remedy in recompensing their disputes. In Jordan there is no tribunal for protecting consumers. Instead, the traditional route is used, involving the application of ordinary civil litigation mechanism in recompensing those adversely impacted by unjust conduct. The objective of this paper is to examine the available litigation mechanism in Jordan for such purpose. The traditional mechanism in Jordan appears to be complicated, time-consuming, and is usually costly, that the process of attaining remedy often costs more than the recovered amount after the resolution of the case. Hence, it does not promote consumer protection.
\end{abstract}

Keywords: Jordan, Consumer Protection, Consumer Claims Tribunal, Jordanian Civil law 1976, Draft Law 2013

DOI: $10.7176 / \mathrm{JLPG} / 103-13$

Publication date: November $30^{\text {th }} 2020$

\section{Introduction}

In developing countries such as Jordan, consumer protection research is quite new. Meanwhile, there has been impetus towards the strictness of consumer protection through the introduction of specific laws but the development has been highly premature. In order to assure effectiveness of consumer protection in Jordan, coordination, participations, and collaborations are necessary from all the stakeholders ${ }^{1}$ together with the consumer. A vital role is played by the consumers as they must express or communicate their complaints or dissatisfaction before actions or remedies can be taken in place. ${ }^{2}$ This involves the consumers having the knowhow about their rights, for instance, the knowhow of the complaint registered by a consumer, its procedures, and the appropriate actions against this complaint in accordance with the stipulated regulations.

A consumer is considered the start and the end points of any product regardless of its features and is the start and the end of any economic study regardless of its forms or research methods. Indeed, a consumer is considered the end of everything since he/she is the target place for any different-level decisions whether issued by a civil or an executive body. ${ }^{3}$

Consumer has the right to obtain information related to goods or services of certain type, grade, standard, composition, quantity, quality, model or style. Meanwhile, the goods have specific history or prior use, while the services are of a specific kind, quantity, standard or quality. ${ }^{4}$ Pertinently, information relates to the presence, exclusion or impact imparted by any condition, assurance, right or remedy. Equally, information can be referred to where the goods came from originally, and the consumers have right to know the real or actual price, when they want to purchase a product, including the taxes that must be paid. ${ }^{5}$ Hence, consumers have the right to have a quick and simple solution in recompensing their disputes. ${ }^{6}$

\footnotetext{
${ }^{1}$ Ishak, Suraiya, and Nur Faridah M. Zabil. "Impact of consumer awareness and knowledge to consumer effective behavior." "Asian Social Science 8, no. 13 (2012)": 108.

${ }^{2}$ Azrina, A., H. K. Hock, R. R. Muhammad, and S. A. Y. Sakina. "Quality and labeling of minerals in selected bottled mineral water." "In International Conference on Consumer Law. 2011".

${ }^{3}$ Shuaib, Fatima Zahrah bin Taleb." Role of trademark in consumer protection, a comparative study", Faculty of Higher Education, “University of Jordan”, (2011).

${ }^{4}$ Ismail, Rahmah, Sakina Shaik Ahmad Yusoff, Shamsuddin Suhor, Azimon Azimon Aziz, Muhammad Rizal Razman, and Kartini Aboo Talib. "Consumer Right to Safe Product: The Application of Strict Criminal Liability in Product Safety Legislations in Malaysia." Journal of Social Sciences \& Humanities 20, no. S (2012).

${ }^{5}$ Ishak, Suraiya, and Nur Faridah M. Zabil. "Impact of consumer awareness and knowledge to consumer effective behavior."” Asian Social Science 8, no. 13 (2012)": 108.

${ }^{6}$ Yuthayotin, Sutatip. Access to Justice in Transnational B2c E-commerce: A Multidimensional Analysis of Consumer
} 
It is therefore important to have legislature intervention as this will allow appropriate level of consumer protection. In fact, from an economic perspective, consumers are the weaker party, lacking experience and legal knowledge. Also, considering that consumers depend on the information furnished by the business in making a transactional decision, they are viewed as vulnerable.

\section{Jordanian Legal System}

Jordan is a hereditary constitutional monarchy with a government of parliamentary system bound by the constitution decreed in $1952 .{ }^{1}$ Meanwhile, the law of Jordan is comparable to the Ottoman law, and the Constitutions of Jordan of 1948 and 1952 uphold Islam as the religion of the state. In this country, the highest law is the Islamic law, and next in line are the Constitution, international agreements and national laws, and customary practices. Interestingly, the Jordanian Criminal Law is comparable to the French Penal Code of $1810 .^{2}$

The constitution of Jordan illustrates the country's ruling system; it entails a parliamentary with a hereditary monarchy whereby His Majesty the King leads the three divisions of the state which are the executive, legislative and judicial.

The legal system in Jordan is comparable to civil law jurisdiction as in the French model. Here, the legislative authority is the party responsible in codifying rules into inscribed statutes. ${ }^{3}$ A civil law system is distinct from a common law system, and countries generally have inclusive legal frameworks which provide the details of all matters, and in handling novel issues, the legislation is consistently updated. Update is necessary to legislation because this will to prevent the occurrence of significant gaps especially in contemporary issues such as consumer protection.

The Shari'a also has influence on Jordanian legislation. This can be attributed to fact that the Jordan Civil law 1976 (JCL 1976), which is the main source of all divisions of private law, ${ }^{4}$ and the substitute pertinent law when rules are not available ${ }^{5}$ (e.g., consumer related issues), have to be construed within the realm of 'fiqh' Islamic jurisprudence. Furthermore, Section 2 of the JCL 1976 provides that Shari'a law should become the alternative in the absence of rules, as follows:

"(2) If the court finds no applicable provision in this Law [this applies to all other enactments] to the issue in question, it shall resort to the rules of Islamic Fiqh (Jurisprudence) which are more adaptable to the provisions of this Law, and in case there is none, it shall resort to the principles of the Shari'a;

(3) And, if there is none, resort shall be made to the custom, and if there is none then to the rules of equity...;

(4) In all the above, guidance shall be drawn from judicial decisions and jurisprudence provided that they are not repugnant thereto". 6

\section{The Judiciary in Jordan}

In Jordan, the Judiciary is sovereign and this division is to be executed by the courts of law in differing levels and types. The judgments must all be presented following the law and enunciated in the name of the King. ${ }^{7}$ There are three court systems in this country as follows: Civil courts, Military courts and Religion courts. Specifically, civil courts comprise Courts of Appeal, Magistrates' Courts, Major Felonies Courts, and Cassation Court (Supreme Court). It should be noted that the Constitution of Jordan in Section 97 provides that judges are autonomous and are only bound to the authority of the Law. Relevantly, based on the Law provision, a Royal Decree is the body that dismisses and appoints the judges of civil and religious (Shari'a) courts. ${ }^{8}$

Civil Courts in Jordan shall have dominion over all people particularly regarding individual, criminal and civil matters, and these also include matters raised by or against the government, with the exception of situations where jurisdiction is entrusted and conferred in Special Courts or Religious Courts based on the present

Protection Mechanisms. Springer, 2014

${ }^{1}$ The constitution in Jordan has been amended in 2011.

${ }^{2}$ Alhusban, Ahmad. "The Importance of Consumer Protection for the Development of Electronic Commerce: The Need for Reform in Jordan." "PhD diss., University of Portsmouth, (2014).

${ }^{3}$ Ibid.

${ }^{4}$ Abdelnaser Hayajneh, 'Legal Surgery: the Need to Review Jordanian Civil Law', " British Journal of Humanities and Social Sciences," (2012).

${ }^{5}$ Adnan Alsarhan, “Jordan Civil Code: Sources of Obligations", 1st, "DarAlthaqafah, Amman” (2005) (In Arabic).

${ }^{6}$ Jordan Civil Law1976.s (2).

${ }^{7}$ The Jordanian Constitution 1952. S (27), Amended in 2011.

8 The Jordanian Constitution 1952. s (98). 
provisions of constitution or any other legislation in power.

In Jordan, the only way for customer to acquire compensation is the traditional way, and this traditional way has been followed whenever any problem occurred in the commercial contracts. The use of traditional way is factored by the absence of rule and regulation related to problems of consumer, particularly those associated with the internet. ${ }^{2}$ The traditional way is exemplified in the regular civil litigation method for paying off groups unfavourably affected by illegal conducts. This old method can be explained as multifarious, time-consuming and mostly high in cost, and this clearly does not encourage the protection of consumer, as consumers are generally imparted with only small portion of benefits and allowances. ${ }^{3}$

Also, individual lawsuits have been found ineffective in halting imbalanced commercial practices or even in providing recompense for the harm that such practices have caused to consumer. ${ }^{4}$ In fact, it is not uncommon for consumers to eventually surrender their claim because it is often that the litigation cost is higher than the claimed amounts. ${ }^{5}$

Comparatively, the court-based/judicial mechanism of redress in the UK is generally deemed as a last resort ${ }^{6}$ because consumers are provided with various means and processes should they wish to seek redress from a given business. The in-house complaints procedures or an alternative dispute resolution (ADR) are among the examples. 'Also, in the UK, businesses in certain sectors are required by the regulations to have an in-house complaints mechanism"?

\section{Discussion a Create Consumer Claims Tribunal}

In Jordan, whenever a dispute arises involving a consumer and a business, the only accessible route for redressing this adversely affected consumer is the traditional one, which is exemplified in the conventional civil litigation mechanism. In this regard, Civil Courts are the courts that will handle such matter, as provided in Law No. 17 of $2001 .{ }^{8}$ As mentioned earlier, Civil Courts have jurisdiction over all individuals in all criminal and civil matters, which include matters over which special or religious courts have authority based on the stipulations of any other law. ${ }^{9}$ Civil (regular) courts include Magistrate (sulh) Courts, Courts of First Instance, Courts of Appeals, and Court of Cassation.

The traditional mechanism is generally time-consuming, complex and often costly. Such attributes impede consumer protection, especially when consumers only will receive recompense of small amount, ${ }^{10}$ and such low amount of recompense in comparison to the litigation cost often forces consumers to not pursue the case. ${ }^{11}$ Also, consumer disputes often extend, surpassing the issue of faulty or defective goods; the disputes may extend to the issues of lack of conformity, provision of imprecise technical information in regards to the terms and conditions, or tangible goods or software of low quality. ${ }^{12}$

An online survey has been used in this study, specifically through the use of survey monkey, with the purpose obtaining responses about the awareness of consumers pertaining to the establishment of a Consumer Claims

${ }^{1}$ The Constitution in Jordan 1952. s (102).

${ }^{2}$ Al Sharu, Ahmad Ibrahim, Fauziah Binti Mohd Noor, and Rohana Binti Abdul Rahman. "Legislation on Consumer Protection against Misleading Advertisement: A Comparative Studies between Jordanian Legislation and Malaysia Consumer Protection Law 1999." ABC Research Alert 7, no. 2 (2019).

${ }^{3}$ Alhusban, Ahmad. "The Importance of Consumer Protection for the Development of Electronic Commerce: The Need for Reform in Jordan." "PhD diss., University of Portsmouth, (2014)".

${ }^{4}$ European Commission, 'Towards a Coherent European Approach to Collective Redress' (Public Consultation SEC (2011)0173 2011) Para 4.

${ }^{5}$ The European Consumer Centres' Network, "The European Online Marketplace Consumer Complaints 2010-2011" [September 2012]

Available on http://ec.europa.eu/consumers/ecc/docs/e-commerce-report-2012_en.pdf Accessed on September 2017.

${ }^{6}$ Fairgrieve, Duncan, and Geraint Howells. "Collective Redress Procedures-European Debates." "International and Comparative Law Quarterly 58, no. 2 (2009)": 379-409

${ }^{7}$ See: Hodges, Christopher. "Mass Collective Redress: Consumer ADR and Regulatory Techniques." "European Review of Private Law 23, no. 5 (2015)": 829-873.

${ }^{8}$ Jordanian Law of forming the regular courts. (2001), No. (17)

${ }^{9}$ Jordanian Law of forming the regular courts (2001).s (2).

${ }^{10}$ Alhusban, Ahmad. "The Importance of Consumer Protection for the Development of Electronic Commerce: The Need for Reform in Jordan." PhD diss., University of Portsmouth, (2014).

${ }^{11}$ Ibid.

${ }^{12}$ Alhusban, Ahmad. "The Importance of Consumer Protection for the Development of Electronic Commerce: The Need for Reform in Jordan." PhD diss., University of Portsmouth, (2014). 
Tribunal in Jordan. The items in the survey were devised to collect opinions of consumers about having a consumer tribunal or special court in Jordan for protecting the consumers. The majority of respondents stated that it is a good idea to have such kind of courts, and that Jordan needs to have a court or tribunal which is specialized in the protection of consumers.

Do you like to have consumer/tribunal court in Jordan?

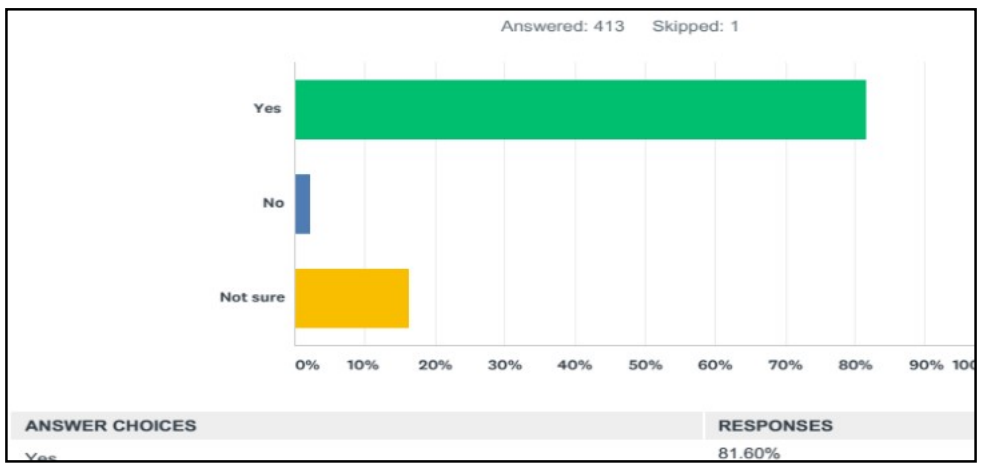

The formation of Jordan courts focusing on customer safety was considered a good step towards endorsing customer rights, particularly towards defence against confusing commercial. Such courts will also increase judges' skills in imparting judgments on customer safety clashes. Furthermore, disputes will be dealt with more rapidly, with consideration to the nature of such clashes. Therefore, any losses that might happen owing to lengthy disputes which may take numerous years before a final judgement is reached, will be evaded. It is crystal clear from the above discussion and from the data collected from the online survey that there is a crucial need for Jordan to have a special court on consumer protection.

By special court with competent legal power to deal with the parties of contract, the customer can get remedy for their cases or complaint. Meanwhile, the governmental tribunal will provide simple, inexpensive and fast alternate. In addition, the tribunal should provide easy and fast procedures whereby cases can be settled in less than 60 days from the date of filing. Notably, the judgment imposed by the tribunal is final, and therefore, the involved parties cannot appeal, except, if it is on a point of law.

The court and / tribunal should have discretion in determining forms, for example, misleading advertising or deception, fraud, and so forth. On the other hand, more experts in protection of consumer should be employed to assist the court/ tribunal upon request. For instance, the role of Food and Drug Administration or Consumer Protection Association experts would be to provide advice on the application and request of consumer protection law on cases requiring experts' view and opinion.

\section{Conclusion}

The ordinary civil litigation mechanism for compensating consumer is often time-consuming, complicated and costly, and this dampens the efforts towards consumer protection, especially when consumers are only awarded with small amount of compensation. Instead of going to the court, consumer can also use alternative dispute resolution namely "Arbitration procedure" (ADR). However, ADR is not available as there is no agreement among the parties, consumer and advertiser. Moreover, the Draft Law 2013 does not mention arbitration as a way to settle the dispute.

The study found that the current Jordanian legal system by ordinary civil litigation mechanism does not provide consumers with sufficient protection. Based on the finding of the study, it is hoped that the Jordanian Government will establish a specialized tribunal for the consumers.

\section{References}

Lawrence, S. et al. (2001). Persistence of Web References in Scientific Research. Computer. 34, $26-31$. doi:10.1109/2.901164, http://dx.doi.org/10.1109/2.901164

Smith, Joe, (1999), One of Volvo's core values. [Online] Available: http://www.volvo.com/environment/index.htm (July 7, 1999) 
Strunk, W., Jr., \& White, E. B. (1979). The elements of style. (3rd ed.). New York: Macmillan, (Chapter 4).

Van der Geer, J., Hanraads, J. A. J., \& Lupton R. A. (2000). The art of writing a scientific article. Journal of Scientific Communications, 163, 51-59

Azrina, A., H. K. Hock, R. R. Muhammad, and S. A. Y. Sakina. "Quality and labeling of minerals in selected bottled mineral water. In International Conference on Consumer Law. 2011.

Shuaib, Fatima Zahrah bin Taleb." Role of trademark in consumer protection, a comparative study", Faculty of Higher Education, “University of Jordan”, (2011).

Ismail, Rahmah, Sakina Shaik Ahmad Yusoff, Shamsuddin Suhor, Azimon Azimon Aziz, -Muhammad Rizal Razman, and Kartini Aboo Talib. "Consumer Right to Safe Product: The Application of Strict Criminal Liability in Product Safety Legislations in Malaysia." Journal of Social Sciences \& Humanities 20, no. S (2012).

Ishak, Suraiya, and Nur Faridah M. Zabil. Impact of consumer awareness and knowledge to consumer effective behavior. Asian Social Science 8, no. 13 (2012): 108.

Yuthayotin, Sutatip. Access to Justice in Transnational B2c E-commerce: A Multidimensional Analysis of Consumer Protection Mechanisms. Springer, 2014.

Alhusban, Ahmad. The Importance of Consumer Protection for the Development of Electronic Commerce: The Need for Reform in Jordan. PhD dissertation., University of Portsmouth, (2014).

Abdelnaser Hayajneh, 'Legal Surgery: The Need to Review Jordanian Civil Law. British Journal of Humanities and Social Sciences, (2012).

Adnan Alsarhan, "Jordan Civil Code: Sources of Obligations", 1st, Dar Althaqafah, Amman (2005) (In Arabic).

Al Sharu, Ahmad Ibrahim, Fauziah Binti Mohd Noor, and Rohana Binti Abdul Rahman. Legislation on Consumer Protection against Misleading Advertisement: A Comparative Studies between Jordanian Legislation and Malaysia Consumer Protection Law 1999. ABC Research Alert 7, no. 2 (2019).

European Commission, 'Towards a Coherent European Approach to Collective Redress' (Public Consultation SEC (2011)0173 2011) Para 4.

The European Consumer Centers' Network, “The European Online Marketplace Consumer Complaints 20102011" [September 2012] Available on http://ec.europa.eu/consumers/ecc/docs/e-commerce-report-2012_en.pdf Accessed on September 2017.

Fairgrieve, Duncan, and Geraint Howells. Collective Redress Procedures-European Debates. International and Comparative Law Quarterly 58, no. 2 (2009)”: 379-409.

Hodges, Christopher. Mass Collective Redress: Consumer ADR and Regulatory Techniques. European Review of Private Law 23, no. 5 (2015)": 829-873. 